\title{
Checklist, Indeks Ekologi, dan Status Konservasi Komunitas Fauna Akuatik di Kawasan Sungai Unda dan Sekitar Pantai Jumpai, Kabupaten Klungkung, Provinsi Bali
}

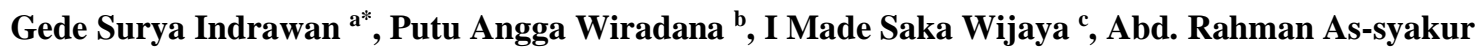 \\ a,d, M. Rheza Rizki Syahputra c ${ }^{c}$ I Made Sara Wijana ${ }^{\text {c,d }}$ \\ ${ }^{a}$ Program studi Ilmu Kelautan, Fakultas Kelautan dan Perikanan, Universitas Udayana, Jl. Raya Kampus Unud, \\ Jimbaran, Kec. Kuta Selatan, Kabupaten Badung, Bali 80361 \\ ${ }^{b}$ Program Studi Biologi, Fakultas Kesehatan, Sains, dan Teknologi, Universitas Dhyana Pura, Jl. Raya Padangluwih, \\ Dalung, Kec. Kuta Utara Kabupaten Badung, Bali 80361 \\ ${ }^{c}$ Program studi Biologi, Fakultas Matematika dan Ilmu Pengetahuan Alam, Universitas Udayana, Jl. Raya Kampus \\ Unud, Jimbaran, Kec. Kuta Selatan, Kabupaten Badung, Bali 80361 \\ ${ }^{d}$ Pusat Penelitian Lingkungan Hidup (PPLH), Universitas Udayana, Jl. PB. Sudirman, Denpasar, Bali
}

*Email: suryaindrawan@unud.ac.id

Diterima (received) 13 Desember 2020; disetujui (accepted) 1 Februari 2021; tersedia secara online (available online) 1 Februari 2021

\begin{abstract}
Aquatic organisms or nekton have an important role in supporting the stability of the aquatic environment and human life. This study aims to determine the nekton type community, ecological index, and their conservation status in the Unda River area and around Jumpai Beach, Klungkung Regency, Bali. The study was conducted in July - August 2020. The study was conducted in 2 communities, namely Macrozoobenthos and Nekton. Macrozoobenthos samples were collected using the quadratic method in the Jumpai Beach area and the direct observation method along the Unda River. Nekton communities are collected through primary data using "survey methods" and secondary data through interviews with fishermen and local communities. The ecological index data were analyzed using the Shannon-Weiner diversity index $\left(\mathrm{H}^{\prime}\right)$, dominance index $(\mathrm{C})$, and uniformity index (E), while the data on Nekton type and conservation status were analyzed descriptively. The nekton species community in the waters of the Unda River and Jumpai Beach areas was obtained as many as 26 species in 21 families which were dominated by Kepala Timah (Aplocheilus panchax) and sepat rawa (Trichogaster trichopterus), while Nautica $s p$ for the Macrozoobenthos community. The ecological index of the aquatic community is the Shannon-Weiner Diversity Index $\left(\mathrm{H}^{\prime}\right)$ value of 2.98 (moderate), the wealth index (R) of 3.95 (moderate), and the evenness index (E) of 1.21. (High). The highest percentage ratio of nekton communities was obtained by the Macrozoobenthos community, namely 53\%, while the nekton species was $46 \%$. Conservation status shows that 13 species are included in the LC (Least Concern) category, 12 species are included in the NE (Not Evaluated) category, and 1 species are included in the VU (Vulnerable) category.
\end{abstract}

Keywords: conservation; aquatic organism; checklist; ecological index; anthropogenic agent

\section{Abstrak}

\begin{abstract}
Organisme akuatik atau nekton memiliki peranan yang penting dalam menunjang stabilitas lingkingan perairan dan kehidupan manusia. Penelitian ini bertujuan untuk mengetahui komunitas jenis nekton, indeks ekologi, dan status konservasinya di kawasan Sungai Unda dan sekitar Pantai Jumpai, Kabupaten Klungkung, Bali. Penelitian dilakukan pada Bulan Juli - Agustus 2020. Penelitian dilakukan pada 2 komunitas yaitu Makrozoobentos dan Nekton. Sampel makrozoobenthos dikumpulkan dengan metode kuadrat pada kawasan Pantai Jumpai dan Metode pengamatan langsung di sepanjang Sungai Unda. Komunitas nekton dikumpulkan melalui data primer yaitu menggunakan metode "survey methods" dan data sekunder melalui wawancara dengan nelayan dan masyarakat
\end{abstract}

doi: https://doi.org/10.24843/blje.2021.v21.i01.p02

(C) 2019 by the authors; Content from this work may be used under the terms of the Creative Commons Attribution 3.0 licence. Any further distribution of this work must maintain attribution to the author(s) and the title of the work, journal citation and DOI. Published under licence by Udayana University, Indonesia. 
sekitar. Data indeks ekologi dianalisis menggunakan dengan indeks keragaman Shannon-Weiner (H'), indeks dominansi (C), dan indeks keseragaman (E), sedangkan data jenis nekton dan status konservasi dianalisis secara deskriptif. Komunitas spesies akuatik di perairan kawasan Sungai Unda dan Pantai Jumpai diperoleh sebanyak 26 spesies dalam 21 famili yang didominasi oleh Kepala Timah (Aplocheilus panchax) dan sepat rawa (Trichogaster trichopterus) untuk komunitas nekton, sedangkan Natica sp untuk komunitas Makrozoobenthos. Indeks ekologi pada komunitas akuatik adalah Nilai Indeks Diversitas Shannon-Weiner (H') sebesar 2,98 (Sedang), Indeks kekayaan (R) sebesar 3,95 (Sedang), dan Indeks Kemerataan (E) sebesar 1,21 (Tinggi). Persentase perbandingan komunitas akuatik tertinggi diperoleh oleh komunitas Makrozoobenthos yaitu sebesar 53\% sedangkan spesies nekton yaitu sebesar $46 \%$. Status konservasi menunjukkan sebanyak 13 spesies termasuk dalam kategori LC (Least Concern) sebanyak 12 spesies termasuk kategori NE (Not Evaluated), dan 1 spesies termasuk dalam kategori VU (Vulnerable).

Kata Kunci: konservasi; organisme akuatik; checklist; indeks ekologi; agen antropogenik

\section{Pendahuluan}

Prioritas konservasi dunia saat ini adalah untuk dapat mempertahankan dan melindungi keutuhan dan tingkat keanekaragaman hayati baik di lingkungan darat, laut, dan air tawar (Brooks et al., 2006). Indonesia adalah salah satu dari sepuluh negara yang beragam secara ekonomi, sosial, budaya, adat istiadat, suku, dan agama hingga keanekaragaman hayati. Pada ekosistem perairan, Indonesia disebut sebagai negara dengan megabiodiversitas terumbu karang yang paling beragam di seluruh dunia (von Rintelen et al., 2017). Namun, dalam beberapa tahun terakhir telah banyak spesies dan habitat yang telah terancam oleh aktivitas manusia seperti kerusakan terumbu karang, pengerukan dan pembangunan resort pariwisata, limbah industri dan pertanian, tumpahan minyak, hingga penangkapan ikan yang dilakukan secara masif (Cleary \& DeVantier, 2011).

Laporan menyebutkan bahwa ekosistem perairan telah mengalami ancaman yang paling serius akibat berbagai aktivitas manusia. Perubahan iklim merupakan salah satu penyebab terjadinya perubahan daya adaptasi organisme perairan pada habitat aslinya sehingga mampu mengubah faktor abiotik (misalnya Curah hujan) yang mempengaruhi fungsi normal ekosistem perairan termasuk daya reproduksi dan kebiasaan makan organisme akuatik (Schmeller et al., 2018). Sehingga untuk dapat tetap melindungi keberlangsungan spesies perairan dan memastikan fungsi ekologis berjalan dengan baik, sangat penting untuk dilakukan sebuah kajian atau monitoring mengenai indeks ekologi, status organisme, hingga rekomendasi yang tepat pada ekosistem perairan di suatu habitat.

Sungai Unda dan wilayah perairan Pantai Jumpai merupakan salah satu kawasan di Bali merupakan salah satu daerah yang banyak dimanfaatkan oleh penduduk sekitarnya untuk kegiatan memancing hingga nelayan untuk memperoleh hasil perikanan. Oleh karena itu, penelitian ini bertujuan untuk mengetahui 1) checklist komunitas akuatik, 2) status konservasi, dan 3) indeks ekologi di perairan Tukad Unda dan wilayah pantai Jumpai, Klungkung, Bali. Penelitian ini diharapkan mampu memberikan informasi khusunya dalam upaya konservasi dan manajemen lingkungan perairan di wilayah Tukad Unda dan sekitar pantai Jumpai, Klungkung.

\section{Metode Penelitian}

\subsection{Waktu dan Area Penelitian}

Penelitian eksplokasi komunitas nekton dilakukan di kawasan Sungai Unda dan Pantai Jumpai, Kabupaten Klungkung pada bulan Juli - Agustus 2020. Kajian fauna akuatik dilakukan dengan mengamati komunitas akuatik seperti makrozoobenthos dan nekton di sepanjang perairan Tukad Unda dan Pantai Jumpai (Gambar 1). 


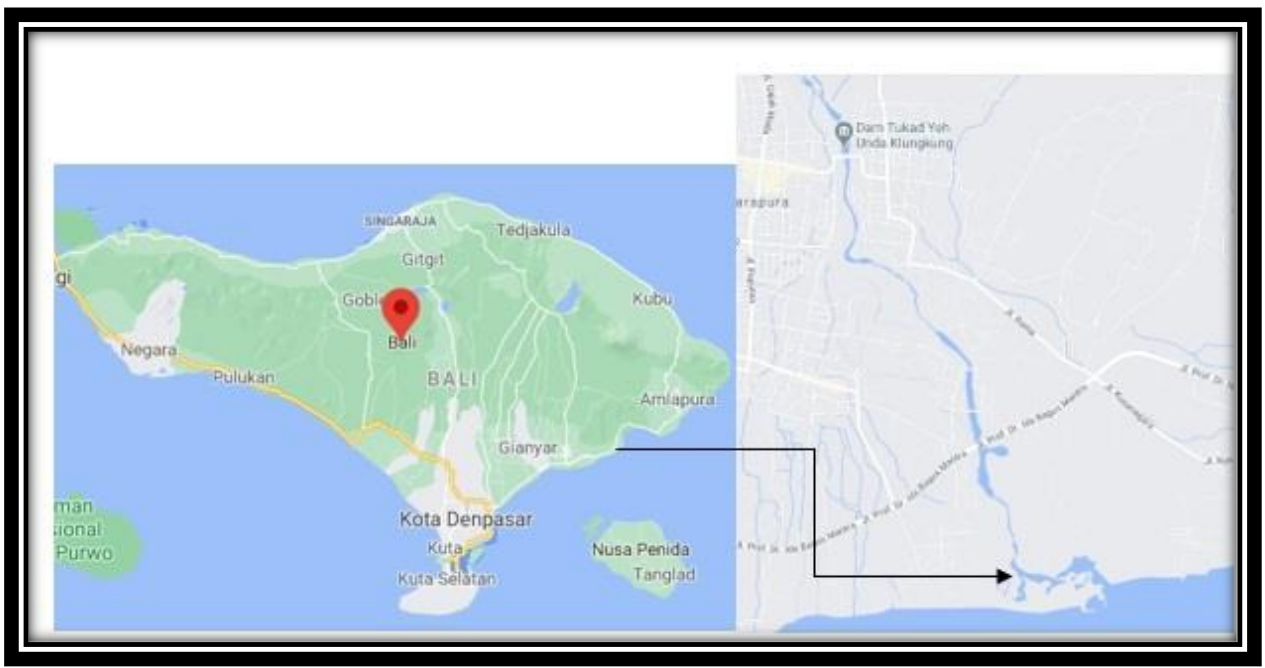

Gambar 1. Lokasi penelitian ditunjukan dengan symbol tanda panah $(\rightarrow$ ) yang meliputi Daerah Aliran Sungai Unda dan Pantai Jumpai di Kabupaten Klungkung, Provinsi Bali (Google Maps, 2020).

\subsection{Alat dan Bahan Penelitian}

Alat yang digunakan dalam penelitian ini berupa Cetok, Sekop, Kuadran berukuran $1 \times 1 \mathrm{~m}^{2}$, kamera digital, ember, meteran, plastik sampling, dan tally sheet. Bahan yang digunakan berupa alkohol $70 \%$ yang digunakan untuk menyimpan sampel di lapangan.

\subsection{Pengumpulan data}

\subsubsection{Komunitas hewan akuatik}

\section{a. Makroozobenthos}

Makrozoobenthos dikumpulkan dari dalam substrat pada dasar perairan (batu dan pasir) dengan menggunakan metode transek kuadrat dengan Panjang transek $100 \mathrm{~m}$ dan menggunakan kuadrat berukuran $1 \times 1 \mathrm{~m}^{2}$. Metode kuadrat dilakukan khusus untuk pengumpulan marozoobentos di daerah Pantai Gunaksa, sedangkan untuk komunitas makrozoobenthos di Sungai Unda dilakukan dengan cara melakukan pengamatan langsung di dasar perairan. Setiap sampel, jenis, dan jumlah makrozoobenthos yang diperoleh dicatat untuk dianalisis lebih lanjut.

\section{b. Nekton}

Pengumpulan data ikan dilakukan pada area perairan baik di Pantai Gunaksa dan Sungai Unda . Jenis - jenis ikan yang dicatat adalah jenis yang paling umum dimanfaatkan oleh masyarakat sekitar dan nelayan. Data primer jenis ikan diperoleh menggunakan "Survey methods" yaitu berdasarkan tangkapan di kawasan penelitian. Alat tangkap yang digunakan berupa jarring berukuran 1.0, 2.0. dan 3.0 inchi. Data sekunder diperoleh dari wawancara dengan nelayan dan penduduk yang juga melakukan penangkapan ikan di kawasan penelitian dengan menggunakan jarring/anco.

\subsection{Eksplorasi komunitas hewan akuatik}

Hasil sampling baik makrozoobenthos dan nekton dikumpulkan dan dipreservasi menggunakan alcohol $70 \%$ serta didokumentasi untuk kepentingan identifikasi lebih lanjut menggunakan beberapa 
sumber seperti World Register of Marine Species (WoRMS), FishBase, Dharma (1988;1992), aplikasi Inaturalist dan beberapa jurnal nasional (SINTA) dan international terkait yang diakses melalui ScienceDirect, Springer, dan ResearchGate. Seluruh data yang diperoleh, dikelompokkan berdasarkan komunitasnya baik Makrozoobenthos dan Nekton ke dalam Ms. Excel 2019 dan dianalisis secara deskriptif berupa tabel, gambar, dan grafik. Data pendukung berupa status konservasi diakses melalui laman www.iucnredlist.org, untuk memperoleh status konservasi keanekaragaman hayati secara global serta melalui Peraturan Menteri Lingkungan Hidup dan Kehutanan Republik Indonesia Nomor P.106/MENLHK/SETJEN/KUM.1/12/2018 tentang Perubahan Kedua Atas Peraturan Menteri Lingkungan Hidup dan Kehutanan Nomor P.20/MENLHK/SETJEN/KUM.1/12/2018 tentang Jenis Tumbuhan dan Satwa yang Dilindungi.

\subsection{Analisis Data}

Data yang diperoleh kemudian dianalisis untuk menentukan indeks ekologi yang terdiri dari Indeks Keanekaragaman (H'), Indeks Kekayaan (R), dan Indeks Kemerataan (E). Indeks keanekaragaman (H') ditentukan dengan menggunakan persamaan Shannon-Wierner sebagai berikut :

$$
\begin{gathered}
\text { Indeks Keanekaragaman }\left(H^{\prime}\right)=-\sum p i \cdot \ln . p i \\
\text { Indeks Keanekaragaman }\left(H^{\prime}\right)=-\sum\left\{\left(\frac{n i}{n}\right) \cdot \ln \left(\frac{n i}{n}\right)\right\}
\end{gathered}
$$

Keterangan :

H' = Indeks Keanekaragaman

ni $=$ jumlah individu

$\mathrm{n}=$ jumlah total individu

Indeks kekayaan (R) ditentukan dengan menggunakan persamaan Margalef (1958) dalam Magurran (2004) sebagai berikut :

$$
R=\frac{S-1}{\ln (n o)}
$$

Keterangan :

$\mathrm{R}=$ Indeks Kekayaan Jenis

$\mathrm{S}=$ jumlah total jenis dalam suatu habitat

$\mathrm{n}=$ jumlah total individu seluruh spesies dalam suatu habitat

Indeks Kemerataan ditentukan degan menggunakan persaman dari Hill (1973) sebagai berikut:

$$
E=\frac{1 / S i}{\ln (S)}
$$

Keterangan:

$\mathrm{E}=$ Indeks kemerataan (nilai antara $0-1$ )

$\mathrm{H}^{\prime}=$ Indeks keanekaragaman Shannon-Wiener

$\mathrm{S}=$ Jumlah jenis spesies

\section{Hasil dan Pembahasan}

Spesies di lingkungan akuatik di kawasan Sungai Unda dan Pantai Jumpai diperoleh sebanyak 26 spesies, dimana dibagi menjadi 2 komunitas yaitu komunitas ikan dan makrozoobenthos. Komunitas nekton diperoleh sebanyak 12 spesies dan makrozobenthos sebanyak 14 spesies. Komunitas nekton 
didominasi oleh spesies ikan kepala timah Aplocheilus panchax dan sepat rawa Trichogaster trichopterus, sedangkan komunitas makrozoobenthos didominasi oleh siput bulan (Natica sp.). Spesies ini banyak tersebar di beberapa negara Asia Tenggara seperti Cambodia, Laos, Thailand, Vietnam, Malaysia dan Indonesia (Low \& Lim, 2012). Ikan sepat rawa memiliki habitat di rawa-rawa, danau, aliran sungai dan secara umum di lahan basah di dataran rendah (Cavalcanti \& Lopes, 2017) termasuk di daerah lokasi penelitian di Sungai Unda, Klungkung, Bali yang ditemukan pada areal bekas galian C yang sudah digenangi oleh air. Selain itu, keberadaan ikan ini juga dapat dimanfaatkan sebagai ikan hias di beberapa negara. Spesies ikan kecil lainnya adalah kepala timah Aplocheilus panchax yang keberadaannya sangat melimpah di lokasi penelitian. Ikan kepala timah memiliki bobot badan berkisar $1.52 \pm 0.14 \mathrm{gm}$ (Saha et al., 2018). Selanjutnya untuk komunitas makrozoobenthos seperti Natica sp ditemukan di sebagian besar lokasi sampling terutama di dekat Pelabuhan Gunaksa. Menurut data World Register of Marine Species (WoRMS), Natica sp merupakan siput laut predator berukuran kecil hingga sedang atau sering disebut dengan siput bulan/ moon-snail.

Komunitas nekton yang biasa dikonsumsi oleh masyarakat di kawasan Sungai Unda dan sekitar Pantai Jumpai antara lain, ikan nila (Oreochromis niloticus), ikan mujair (O. mossambicus), ikan belanak (Moolgarda seheli), ikan bandeng (Chanos chanos), ikan gabus (C. striata), ikan kuwe (Caranx sp.), dan ikan cucut (Rhizoprionodon acutus). Seluruh komunitas akuatik yang diperoleh di kawasan Sungai Unda dan sekitar pantai Jumpai tidak termasuk dalam kategori dilindungi berdasarkan Peraturan Menteri Lingkungan Hidup dan Kehutanan Republik Indonesia Nomor p.106/menlhk/setjen/kum.1/12/2018. Sedangkan berdasarkan status IUCN, sebanyak 13 spesies termasuk dalam kategori LC (Least Concern) sebanyak 12 spesies termasuk kategori NE (Not Evaluated), dan 1 spesies termasuk dalam kategori VU (Vulnerable).

Tabel 1. Biota Akuatik di kawasan Pantai Jumpai dan Sungai Unda

\begin{tabular}{|c|c|c|c|c|c|}
\hline No & Nama Lokal & Family & Spesies & $\begin{array}{c}\text { Status } \\
\text { dilindungi }\end{array}$ & $\begin{array}{l}\text { Status } \\
\text { IUCN }\end{array}$ \\
\hline 1 & Kepala timah & Aplocheilidae & Aplocheilus panchax & $\mathrm{TL}$ & $\mathrm{LC}$ \\
\hline 2 & $\begin{array}{l}\text { Estuarine } \\
\text { Ricefish }\end{array}$ & Aplocheilidae & Aplacheilus armatus & $\mathrm{TL}$ & $\mathrm{LC}$ \\
\hline 3 & Ikan kuwe & Carangidae & Caranx ignobilis & $\mathrm{TL}$ & $\mathrm{LC}$ \\
\hline 4 & Ikan cucut & Carcharhinidae & Rhizoprionodon acutus & $\mathrm{TL}$ & $\mathrm{LC}$ \\
\hline 5 & Gastropoda & Cassidae & Semicassis sp. & $\mathrm{TL}$ & $\mathrm{NE}$ \\
\hline 6 & Ikan Bandeng & Chanidae & Chanos chanos & $\mathrm{TL}$ & $\mathrm{LC}$ \\
\hline 7 & Ikan Gabus & Chanidae & Channa striata & $\mathrm{TL}$ & $\mathrm{LC}$ \\
\hline 8 & Mujair & Cichlidae & Oreochromis mossambicus & $\mathrm{TL}$ & VU \\
\hline 9 & Ikan Nila & Cichlidae & Oreochromis niloticus & $\mathrm{TL}$ & $\mathrm{LC}$ \\
\hline 10 & Gastropoda & Columbellidae & Mitrella sp. & $\mathrm{TL}$ & $\mathrm{NE}$ \\
\hline 11 & $\begin{array}{l}\text { Snakehead } \\
\text { cowry }\end{array}$ & Cypraeidae & Monetaria caputserpentis & $\mathrm{TL}$ & $\mathrm{NE}$ \\
\hline 12 & Penyemir bintik & Cyprinidae & Notropis hudsonius & $\mathrm{TL}$ & $\mathrm{LC}$ \\
\hline 13 & $\begin{array}{l}\text { Kepiting } \\
\text { sungai/yuyu }\end{array}$ & Gecarcinucoidea & Parathelphusa convexa & $\mathrm{TL}$ & $\mathrm{NE}$ \\
\hline 14 & Marbled crab & Grapsidae & Pachygrapsus marmoratus & $\mathrm{TL}$ & $\mathrm{NE}$ \\
\hline 15 & $\begin{array}{l}\text { Pelagic Goose } \\
\text { Barnacle }\end{array}$ & Lepadidae & Lepas anatifera & $\mathrm{TL}$ & $\mathrm{NE}$ \\
\hline 16 & Flat periwinkle & Littorinidae & Littorina obtusata & $\mathrm{TL}$ & $\mathrm{NE}$ \\
\hline 17 & Ikan belanak & Mugilidae & Moolgarda seheli & $\mathrm{TL}$ & $\mathrm{NE}$ \\
\hline
\end{tabular}


GS Indrawan, dkk.; Checklist, indeks ekologi, dan status konservasi komunitas hewa akuatik.....

\begin{tabular}{llllll}
\hline & & & & \\
18 & Ikan Gadah & Mugilidae & Mugil cephalus & TL & LC \\
19 & Gastropoda & Nassariidae & Nassarius sp. & TL & NE \\
20 & Siput bulan & Naticidae & Natica sp. & TL & NE \\
21 & Sepat rawa & Osphronemidae & Trichogaster trichopterus & TL & LC \\
22 & Udang sawah & Palaemonidae & Macrobrachium lanchesteri & TL & LC \\
23 & Gastropoda & Patellidae & Patella sp. & TL & NE \\
24 & Wharf crab & Sesarmidae & Armases cinereum & TL & NE \\
25 & Belut rawa Asia & Synbranchidae & Monopterus albus & TL & LC \\
26 & New Zealand & Tateidae & Potamopyrgus antipodarum & TL & LC \\
\hline
\end{tabular}

Keterangan: Daftar spesies biota akuatik di Kawasan Sungai Unda dan pantai Jumpai, Klungkung yang masuk ke dalam kategori Dilindungi (L) dan Tidak Dilindungi (TL) berdasarkan Peraturan Menteri Lingkungan Hidup dan Kehutanan Republik Indonesia Nomor p.106/menlhk/setjen/kum.1/12/2018. Kategori NE (Not Evaluated) dan LC (Least Concern) berdasarkan data IUCN (International Union for Conservation of Nature and Natural Resources)

Data indeks ekologi biota akuatik dapat digunakan untuk mengevaluasi kualitas lingkungan di lokasi penelitian Sungai Unda dan sekitarnya. Nilai Indeks Diversitas Shannon-Weiner (H') di Kawasan Sungai Unda dan Pantai Jumpai sebesar 2,98, Indeks kekayaan (R) sebesar 3,95, dan Indeks Kemerataan (E) sebesar 1,21. Data indeks ekologi komunitas akuatik dapat dilihat pada Tabel 2 berikut. Berdasarkan Indeks Diversitas (H') dengan nilai 2,98 (1,5 - 3,5), dapat diketahui kenaekaragaman hayati biota akuatik termasuk "Sedang". Nilai indeks sedang adalah hal yang umum dijumpai di daerah yang menjadi bekas Galian/Tambang Pasir, sebab hal ini dapat terjadi karena habitat komunitas nekton cenderung dimanfaatkan oleh masyarakat sekitar untuk pemenuhan pangan. Selain itu, ukuran nekton yang diperoleh juga tergolong kecil akibat tingginya aktivitas penangkapan di areal Sungai Unda namun masih diperlukan penelitian lebih lanjut mengenai indeks diversitas khususnya ikan yang ditangkap nelayan di Pantai Jumpai agar memiliki informasi yang lebih lengkap.

Indeks kekayaan spesies (R) juga memiliki nilai sedang yaitu 3,95 dari rentang indeks 3,5 - >5. Status tinggi/rendahnya kekayaan jenis di suatu perairan dapat berkaitan dengan aktivitas penangkapan yang berlangsung di kawasan perairan tersebut, sehingga dapat diketahui bahwa jika dilakukan secara terus-menerus populasi ikan yang berkembang di Sungai Unda akan mulai berkurang. Indeks kekayaan komunitas nekton juga dapat dilihat dari jumlah spesies yang diperoleh yaitu sebanyak 26 spesies dalam 21 famili. Indeks kemerataan termasuk dalam kategori tinggi yaitu sebesar 1,21 $(>0,6)$.

Tabel 2. Indeks ekologi komunitas hean akuatik di kawasan sungai Unda dan sekitar Pantai Jumpai, Klungkung

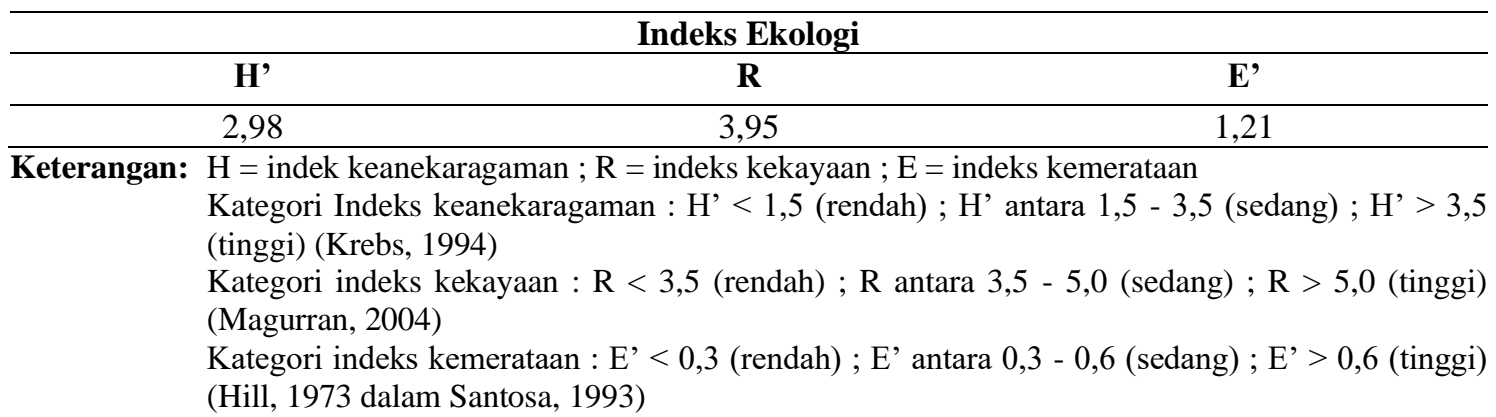


Persentase perbandingan komunitas hewan akuatik tertinggi diperoleh oleh komunitas Makrozoobenthos yaitu sebesar 53\% sedangkan spesies nekton yaitu sebesar $46 \%$. Secara umum, hal ini disebabkan karena makrozoobenthos memiliki kisaran penyebaran yang luas pada berbagai habitat dan substrat khususnya berbatu, berlumpur dan berpasir seperti di kawasan Sungai Unda dan Pantai Jumpai, Klungkung. Lingkungan perairan yang mulai terganggu dapat dilihat dari tingginya spesies makrozoobenthos tertentu. Selain itu, adanya tekanan ekologis yang tinggi di kawasan perairan dapat berakibat menurunnya daya adaptasi organisme tertentu, sehingga hanya organisme yang memiliki daya adaptasi yang tinggi yang akan mulai muncul. Ikan nila merupakan salah satu spesies yang memiliki daya adaptasi yang tinggi terhadap perubahan lingkungan perairan.

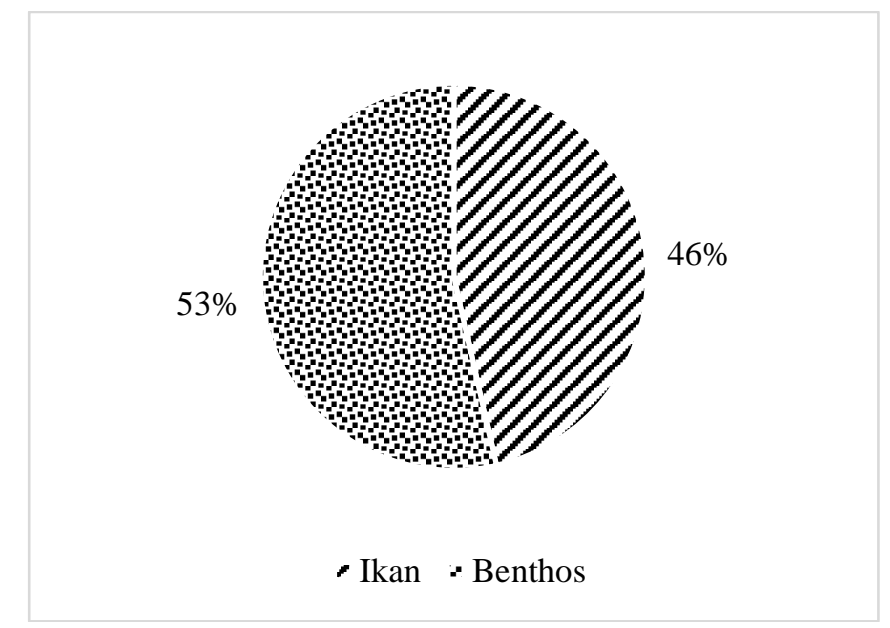

Gambar 2. Perbandingan persentase komunitas nekton di Kawasan Sungai Unda dan Pantai Jumpai, Kabupaten Klungkung, Bali.

Umumnya, ikan nila (Oreochromis niloticus) merupakan ikan air tawar tropis yang memiliki daya tahan tinggi, produktif, dan tumbuh cepat yang banyak dibudidayakan atau ditangkap di alam liar terutama di Afrika dan Asia (El-Sappah et al., 2012). Ikan nila memiliki manfaat bagi manusia karena merupakan bagian utama dari kebutuhan pangan manusia serta penyedia protein yang bermanfaat untuk pemenuhan gizi. Aktivitas anthropogenic berupa galangan kapal, aktivitas rumah tangga, pemukiman penduduk setempat mampu memberikan celah masuknya limbah kontaminan yang mempengaruhi.

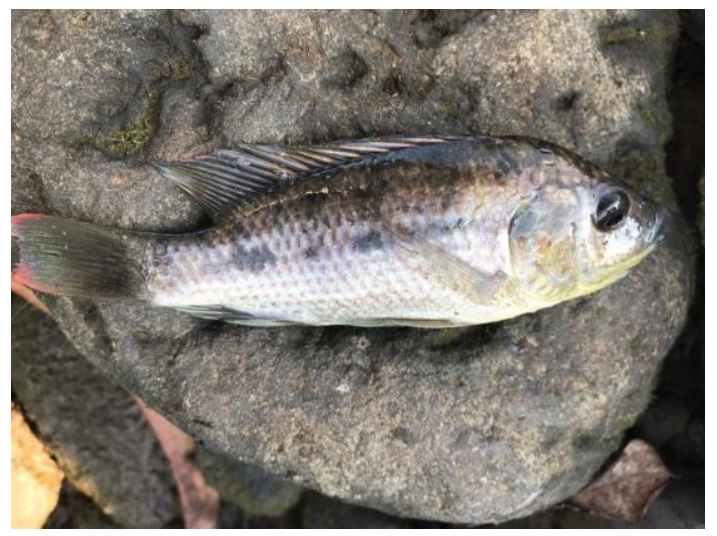

Gambar 3. Ikan Nila (Oreochromis niloticus) yang diperoleh di lokasi penelitian banyak dimanfaatkan sebagai bahan pangan masyarakat sekitar (Peneliti, 2020). 
Peningkatan populasi manusia dan kegiatan industrialisasi mampu menyebabkan terjadinya pencemaran lingkungan pada sebagian besar ekosistem perairan dan penurunan kualitar perairan. Oleh karena itu, organisme yang bertindak sebagai bioindikator ekologis sangat diperlukan untuk dapat meninjau secara dini terjadinya penurunan kualitas lingkungan. Ikan telah diketahui dapat digunakan sebagai bioindikator lingkungan yang dapat berguna untuk meninjau kualitas perairan karena kepekaannya terhadap polusi (Naigaga et al., 2011). Dampak buruk dari terjadinya pencemaran lingkungan perairan terhadap ikan dan manusia adalah munculnya penyakit (Nda et al., 2018).

\section{Simpulan}

Komunitas spesies hewan akuatik di perairan kawasan Sungai Unda dan sekitar Pantai Jumpai diperoleh sebanyak 26 spesies dalam 21 famili yang didominasi oleh Kepala Timah (Aplocheilus panchax) dan sepat rawa (Trichogaster trichopterus) untuk komunitas nekton, sedangkan Natica sp untuk komunitas Makrozoobenthos. Seluruh komunitas akuatik yang diperoleh di kawasan Sungai Unda dan pantai Jumpai tidak termasuk dalam kategori dilindungi dan sebanyak 13 pesies termasuk dalam kategori LC (Least Concern) sebanyak 12 spesies termasuk kategori NE (Not Evaluated), dan 1 spesies termasuk dalam kategori VU (Vulnerable). Indeks ekologi pada komunitas nekton masing-masing adalah Nilai Indeks Diversitas Shannon-Weiner (H') sebesar 2,98 (Sedang), Indeks kekayaan (R) sebesar 3,95 (Sedang), dan Indeks Kemerataan (E) sebesar 1,21 (Tinggi). Persentase perbandingan komunitas hewan akuatik tertinggi diperoleh oleh komunitas Makrozoobenthos yaitu sebesar 53\% sedangkan spesies nekton yaitu sebesar $46 \%$.

Penelitian selanjutnya masih diperlukan untuk dapat memberikan informasi lebih rinci terutama mengenai cemaran logam berat pada organisme akuatik dan kualitas perairan di wilayah sungai Unda, Klungkung. Memberikan edukasi kepada masyarakat sekitar juga diperlukan untuk tetap menjaga kebersihan dan sanitasi lingkungan perairan di kawasan penelitian.

\section{Ucapan terimakasih (bila ada)}

Peneliti mengucapkan terimakasih kepada Pusat Penelitian Lingkungan Hidup (PPLH) Universitas Udayana, Bali yang telah mendukung penelitian ini. Peneliti juga berterimakasih kepada Program Studi Biologi, Fakultas Matematika dan Ilmu Pengetahuan Alam, Universitas Udayana yang telah memberikan ijin melakukan identifikasi fauna akuatik.

\section{Daftar Pustaka}

Brooks, T. M., Mittermeier, R. A., da Fonseca, G. A. B., Gerlach, J., Hoffmann, M., Lamoreux, J. F., Mittermeier, C. G., Pilgrim, J. D., \& Rodrigues, A. S. L. (2006). Global Biodiversity Conservation Priorities. Science, 313(5783), 58-61. https://doi.org/10.1126/science.1127609

Cavalcanti, M. J., \& Lopes, P. R. D. (2017). OCCURRENCE OF THE THREE SPOT GOURAMI Trichopodus trichopterus (ACTINOPTERYGII: OSPHRONEMIDAE) IN GUANABARA BAY, SOUTHEASTERN BRAZIL. Arquivos de Ciências Do Mar, 50(1), 185. https://doi.org/10.32360/acmar.v50i1.18852

Cleary, D. F. R., \& DeVantier, L. (2011). Indonesia: Threats to the Country's Biodiversity. In Encyclopedia of Environmental Health (pp. 187-197). Elsevier. https://doi.org/10.1016/B978-0-44452272-6.00504-3

El-Sappah, A., Shawky, A., Sayed-Ahmad, M., \& Youseff, M. (2012). Nile Tilapia As Bio Indicator To Estimate The Contamination Of Water Using SDS-PAGE and RAPDPCR Techniques. Egyptian Journal of Genetics and Cytology, 41(2), 209-227. https://doi.org/10.21608/ejgc.2012.10536

Low, B., \& Lim, K. (2012). Gouramies of the genus Trichopodus in Singapore (Actinopterygii: Perciformes: Osphronemidae). Nature in Singapore, 5(March), 83-93.

Naigaga, I., Kaiser, H., Muller, W. J., Ojok, L., Mbabazi, D., Magezi, G., \& Muhumuza, E. (2011). Fish as bioindicators in aquatic environmental pollution assessment: A case study in Lake Victoria 
wetlands, Uganda. Physics and Chemistry of the Earth, Parts A/B/C, 36(14-15), 918-928. https://doi.org/10.1016/j.pce.2011.07.066

Nda, A. A., Musa, M. A., Yakubu, S. O., \& Masaya, A. H. (2018). Available online www.jsaer.com Review Article Effects of Aquatic Pollution on Fish Health : A Review. 5(4), 36-46.

Saha, D., Pal, S., Mukherjee, S., Nandy, G., Chakraborty, A., Rahaman, S. H., \& Aditya, G. (2018). Abundance and biomass of assorted small indigenous fish species: Observations from rural fish markets of West Bengal, India. Aquaculture and Fisheries, 3(3), 129-134. https://doi.org/10.1016/j.aaf.2018.04.002

Schmeller, D. S., Weatherdon, L. V., Loyau, A., Bondeau, A., Brotons, L., Brummitt, N., Geijzendorffer, I. R., Haase, P., Kuemmerlen, M., Martin, C. S., Mihoub, J.-B., Rocchini, D., Saarenmaa, H., Stoll, S., \& Regan, E. C. (2018). A suite of essential biodiversity variables for detecting critical biodiversity change. Biological Reviews, 93(1), 55-71. https://doi.org/10.1111/brv.12332

von Rintelen, K., Arida, E., \& Häuser, C. (2017). A review of biodiversity-related issues and challenges in megadiverse Indonesia and other Southeast Asian countries. Research Ideas and Outcomes, 3, e20860. https://doi.org/10.3897/rio.3.e20860 